\title{
Acquisition of cervical control through high postures in patients with West Syndrome: a case report.
}

Tamiris Beppler Martins', Shaiane Alves Pires², Tayná Castilho³, Aline Dandara Rafael³, Micheli Martinello, Gilmar Moraes Santos ${ }^{5}$.

\begin{abstract}
Introduction: early identification of neurological disorders is considered important in the assessment of risk factors and early treatment and subsequently in monitoring the child. Objective: report the lived experiences in a physiotherapy program based on high neuro-evolutive postures in the development of the cervical and trunk control in a child diagnosed with West Syndrome, cerebral palsy and hydrocephalus. Methods: female child, chronological age of four years and five months, motor age less than three months. Kinetic and functional assessment was performed and the Gross Motor Function Measure (GMFM) and the Gross Motor Function Classification System (GMFCS) was used to characterize the subject. Results: there was an increase to $68.6 \%$ in the GMFM, maintaining the level of the GMFCS, improvement of cervical and trunk control in sitting and standing position and when were performed postural changes. Conclusion: the physiotherapeutic care proved to be beneficial in the gradual development of cervical and trunk motor control.

Keywords: Physical Therapy Specialty, Child Development.
\end{abstract}

\section{INTRODUCTION}

The psychomotor development (PD) starts in the intrauterine environment and follows a sequence involving physical growth, neurological maturation and development of cognitive, social, behavioral and affective skills. ${ }^{(1)}$ Such behaviors occur by the interaction between the perceived task, the individual and the environment, so that the motor skills are becoming increasingly organized and complex. ${ }^{(2,3)}$

However some biological and environmental conditions can interfere with this process causing delays in PD. ${ }^{(4)}$ The low birth weight, prematurity, neurological disorders, neonatal infections, cardiovascular and respiratory disorders, among others, are considered risk factors for delay. ${ }^{(2)}$

Among other neurological disorders, West Syndrome (WS), cerebral palsy (CP) and hydrocephalus are associated with delays or declines in the PD. ${ }^{(5,6)}$ Still, limitations on posture and movement patterns are present and interfere with postural control and functional capacity of these children, which makes it necessary to facilitate their motor skills, as well as preventing these musculoskeletal disorders. ${ }^{(7,6)}$
Early identification of neurological disorders is considered important in the assessment of risk factors and early treatment and subsequently in monitoring the child. ${ }^{(8)}$

The physiotherapeutic intervention has an important role in minimizing presented motor difficulties and should be directed to promote experience and practice of the movements that will be incorporated into the child's motor repertoire. ${ }^{(9)}$

Thus, characteristics and stimuli from the environmental in which the child interacts are relevant, since the influence of the social and physical context is also responsible for the condition and clinical evolution of the child. ${ }^{(10-12)}$

So far, was found only the study of Haginoya (1999) in which was reported a case of a child with WS and hydrocephalus. However, no studies were found with children whose clinical diagnosis involves WS, CP and hydrocephalus, and which emphasizes the physiotherapeutic intervention applied. ${ }^{(13)}$

Thus, this study aims to report the lived experiences in a physiotherapy program based on high neuro-evolutive positions in the development of the cervical and trunk control in a child diagnosed with WS, CP and Hydrocephalus. 


\section{CASE DESCRIPTION}

A female child with clinical diagnosis of WS, CP and hydrocephalus, chronological age of four years and five months and motor age of three months participated in the study.

Data collection was performed at the School of Physiotherapy Clinic in the Health and Sports Sciences Center (CEFID) of Santa Catarina State University (UDESC), from March to June 2013, with the following protocol number: 263/2009.

The motor intervention occurred for two months in a period of 40 minutes twice a week, resulting in a total of 15 sessions.

A form containing anamnesis and physical examination (reflexes and postural reactions, postural change and motor performance in each position) was used for kinetic and functional evaluation.

The Gross Motor Function Measure (GMFM) and the Gross Motor Function Classification System (GMFCS) was used to characterize the subject. ${ }^{(14,15)}$

\section{Case Report}

Child named A.C.B.S., four years and five months, female, natural childbirth at term with birth-weight of $2665 \mathrm{~g}, 46 \mathrm{~cm}$ height, head circumference of $34 \mathrm{~cm}$ and Apgar of 9 and 10 in 1 o and 5 o minute, respectively. No prenatal and perinatal complications.

Epilepsy with subsequent diagnosis of WS, CP and hydrocephalus started with two months of age.

She underwent surgery, among which, the placement of ventriculoatrial shunts.

\section{Initial Evaluation}

The GMFCS and the GMFM was applied in dimension A (lie down and roll). GMFCS ranked the subject at the level $V$ and according to GMFM the score was $8.6 \%$.

In supine was verified the preference of the head position to the right and active movement of upper limb surpassing the midline; in prone showed no cervical extension and upper limb support with trunk extension; when placed in sitting and standing position, requires maximum assistance and does not respond with cervical and trunk control.

In postural changes, performed log rolling from supine-toprone with preference to the left and in other positions have no aid in any movement.

Among the evaluated postural reactions and reflections, was observed the absence of the Rectification Reaction and the presence of the Babinski reflex bilaterally.

In postural evaluation was observed the presence of thoracic scoliosis with left convexity, lumbar kyphosis and equinovalgus feet.

\section{Intervention}

Based on the initial evaluation, the treatment objectives were set to stimulate the comprehensive development of the child. The intervention from high postural changes was chosen with the intention of improving the antigravity control.
The procedures used were as follows:

1) Sitting position with the use of balls and rollers and the posterior support of the therapist in the head and trunk;

2) Standing position with subsequent support of the therapist, performing latero-lateral and anteroposterior discharge of weight;

3) Transfer from sitting to standing with maximum assistance of the therapist;

To the postural changes and maintenance of the postures were used as therapeutic resources a knee extension device and ankle-foot orthosis bilaterally. The supports were used in the frontal region, trunk and lower limbs by the therapist.

In all the attendances performed, was reinforced the necessity of encourage the active movement of the patient in the home environment most of the time in sitting position and postural changes. Also, were passed guidelines regarding the use of parapodium at home.

\section{Final Evaluation}

After the proposed physiotherapeutic intervention, was noted in the final evaluation that the GMFM score increased to $68.6 \%$ (dimension A) and GMFCS remained at the same level.

In supine was verified a better alignment of the head and bilateral active movement; when placed in the prone position on the proprioceptive ball, performed cervical and trunk extension with the support of the upper limbs; when placed in the sitting position and standing at the end of the 12 attendances, the patient maintained the cervical and trunk control, requiring only support in the hip region.

Moreover, in postural changes, rolling was performed with low waist dissociation and transfers from sitting to standing and from squatting to standing needed moderate assistance, starting every move and staying in the position for a few minutes.

Regarding the reflexes, the Babinski reflex was still present, but in lower amplitude and apparently the low waist dissociation in the movement of rolling benefited the Rectification Reaction.

In the posture evaluation was observed that the thoracic scoliosis with left convexity and the equinovalgus feet were still present, but the lumbar kyphosis decreased once the patient in sitting position remained with a better biomechanical alignment.

\section{DISCUSSION}

The aim of this study was to report the lived experiences in a physiotherapy program based on high neuro-evolutive postures in the development of the cervical and trunk control in a child diagnosed with west syndrome, cerebral palsy and hydrocephalus. 
According to the initial results of GMFM and GMFCS, were observed severe restrictions in active mobility. Children with severe impairment, i.e., classified in four or five levels of the GMFCS tend to have percentiles below $30 \%$ in the GMFM. ${ }^{(16-18)}$

According to the clinical evaluation of motor function by GMFM-88, the average cutoff point is $40 \%$, which represents children with lower capacity in motor skills. ${ }^{(19)}$ In this study, the GMFM percentile was $8.6 \%$ and after the intervention this score was increased to $68.6 \%$, indicating a better motor performance.

The severe motor impairment is related to the delay in the development of cervical control. ${ }^{(18)}$ In the subject of this study was visualized that cervical and trunk control did not appear completed after physiotherapeutic intervention, however, was observed maintenance in postures with considered postural control and a greater active movement of the patient, in which she did not perform in the initiation of treatment.

In the intervention performed in this study was attempted to emphasize high postures, aiming to the comprehensive development of the child. According to Pacheco et al. (2012), physiotherapy is essential for children with neurological disorders reported here. ${ }^{(20)}$

The postural change from sitting to standing position is often trained during rehabilitation, being characterized as the coordinated action of all body segments, as well as the displacement of the body mass of a large support base until reaching a lower base which is the orthostatic position. ${ }^{(21-23)}$

The realization of the training focused on postural change used in this study cannot be beneficial when thinking about disease prognosis, but when it concerns the musculoskeletal alignment it is essential. Guidelines for the change of decubitus and maintenance of sitting position and standing position for the home environment are necessary. Also, the implementation of rehabilitation protocols which provide physical, social and cognitive benefits, e.g., standing position in parapodium protocol. ${ }^{(21,24,25)}$

The update and adequate knowledge along with trained professionals is essential to enable an ideal treatment aiming an improvement of the quality of life and the lower dependence of the individual.

\section{CONCLUSION}

The physiotherapeutic care in this case, using predominantly high postures, proved to be beneficial in the gradual development of cervical and trunk motor control and increasing of motor skills assessed by GMFM.

\section{AUTHOR'S CONTRIBUTIONS:}

TBM and TC: Conception and development (from idea to research or article, created the hypothesis); TBM and TC: methodological design (planning methods to generate the results); GMS and MM: Supervision (responsible for the organization and execution of the project and manuscript writing); TBM and TC: Collection and processing of data (responsible for experiments, patients, data organization); SAP, ADR, TC and TBM: analysis / interpretation (responsible for statistical analysis, evaluation and presentation of results); SAP, ADR, TC and TBM: Search on literature (participated in the literature search and survey articles); TBM, TC, ADR and SAP: Writing (responsible for writing a substantive part of the manuscript); GMS and MM: Critical Review (reviewed the intellectual content of the manuscript before the final presentation).

\section{CONFLICTS OF INTEREST}

The authors declare that they have no conflicts of interest in the research.

\section{AUTHOR DETAILS}

${ }^{2}$ Graduanda do curso Bacharelado em Fisioterapia da Universidade do Estado de Santa Catarina (UDESC). Florianópolis, (SC).

${ }^{3}$ Fisioterapeuta graduada pela Universidade do Estado de Santa Catarina (UDESC). Florianópolis, (SC).

${ }^{4}$ Professora Mestre da Universidade do Estado de Santa Catarina (UDESC) do curso de graduação Bacharelado em Fisioterapia, Florianópolis, (SC).

${ }^{5}$ Professor Doutor da Universidade do Estado de Santa Catarina (UDESC) do curso de graduação Bacharelado em Fisioterapia, Florianópolis, (SC).

\section{REFERENCES}

1. Miranda LP, Resegue R, Figueiras ACM. A criança e o adolescente com proble-mas do desenvolvimento no ambulatório de pediatria. J Pediatr. 2003;79:33-42.

2. Willrich A, Azevedo CCF, Fernandes JO. Desenvolvimento motor na infância: influência dos fatores de risco e programas de intervenção. Revista Neurociências. 2009;17(1):51-56.

3. Britto IT, Teixeira IR, Botêlho SM, Nery IG, Caricchio GMN. Concepção de mães acerca do desenvolvimento motor em crianças de 0 a 12 meses. Ciência \& Desenvolvimento-Revista Eletrônica da FAINOR. 2011;4(1):144172.

4. Nascimento R, Piassão C. Avaliação e estimulação do desenvolvimento neuropsicomotor em lactentes institucionalizados. Revista Neurociências. 2010;18(4):496-478.

5. Monteiro M, Matos AP, Coelho R. A adaptação psicológica de mães cujos filhos apresentam Paralisia Cerebral: Revisão da literatura. Revista Portuguesa de Psicossomática. 2002;4(2):149-178.

6. Martinello M, Medeiros DL, Piucco EC, Ries LGK. Parâmetros cinemáticos da marcha de criança com paralisia cerebral: Comparação entre diferentes formas de apoio. Cadernos de Terapia Ocupacional da UFSCar. 2014;22:137-143.

7. Ries LGK, Michaelsen SM, Soares PSA, Monteiro VC, Allegretti KMG. Adaptação cultural e análise da confiabilidade da versão brasileira da Escala de Equilíbrio Pediátrica (EEP). Rev Bras Fisioter. 2012;16(3):20515.8.

8. Accardo PJ, Hoon AH. The challenge of cerebral palsy classification: The ELGAN study. Journal of Pediatrics. 2008;153:452-452.

9. Brianeze ACGS, Cunha AB, Peviani SM, Miranda VCR, Tognetti VBL, Rocha NACF, et al. Efeito de um programa de fisioterapia funcional em crianças com paralisia cerebral associado a orientações aos cuidadores: estudo preliminar. Fisioterapia em Pesquisa. 2009;16(1):40-45.

10. Mancini MC, Alves ACM, Schaper C, Figueiredo EM, Sampaio RF, Coelho ZAC, et al. Gravidade da paralisia cerebral e desempenho funcional. Revista Brasileira de Fisioterapia. 2004;8(3):254-60.

11. Monteiro CBM, Jakabi CM, Palma GCS, Torriani-Pasin C, Meira Junior CM. Aprendizagem motora em crianças com paralisia cerebral. Rev. Bras. Cresc. e Desenv. Hum. 2010;20(2):250-262.

12. Arroyo $\mathrm{CT}$, Oliveira SRG. Atividade aquática e a psicomotricidade de crianças com paralisia cerebral. Motriz. 2007;13(2):97-105.

13. Haginoya K, Kona K, Tanaka S, Munakata M, Kato R, Nagai M, et al. The origin of hypsarrhythmia and tonic spasms in West syndrome: evidence from a case of porencephaly and hydrocephalus with focal hypsarrhythmia. Brain and Development. 1999;21(2):129-131. 
14. Russell DJ, Leung KM, Rosenbaum PL. Accessibility and perceived clinical utility of the GMFM-66: evaluating therapists' judgements of a computerbased scoring program. Physical \& Occupational Therapy in Pediatrics. 2003;23(2):45-58.

15. Palisano R, Rosenbaum P, Walter S, Russell D, Wood E, Galuppi B. Gross Motor Function Classification System. Dev Med Child Neurol. 1997;39(4):214-223.

16. Chagas PSC, Defilipo EC, Lemos RA, Mancini MC, Frônio JS, Carvalho RM. Classificação da função motora e do desempenho funcional de crianças com paralisia cerebral. Revista Brasileira de Fisioterapia. 2008;12(5):409416.

17. Cunha AB, Polido GJ, Bella GP, Garbellini D, Fornasari CA. A Relação entre alinhamento postural e desempenho motor em crianças com paralisia cerebral. Fisioterapia em Pesquisa. 2009;16(1):22-27.

18. Martinello M, Levone BR, Piucco EC, Ries LGK. Desenvolvimento do controle cervical em criança com encefalopatia crônica não-progressiva da infância. HU Revista (UFJF. Impresso). 2010;36:209-214.

19. Avery L M, Russell DJ, Raina PS, Walter SD, Rosenbaum PL. Rasch Analysis of the Gross Motor Function Measure: Validating the Assumptions of the Rasch model to Create an Interval-Level Measure. Archives Physical Medicine and Rehabilitation. 2003;84:697-705.
20. Pacheco R, Machado L, Fraga DB. Intervenção fisioterapeutica na encefalopatia crônica não progressiva tipo quadriparesia espástica associada à Síndrome de West. Revista Técnico Científica do IFSC. 2012;1(2):258.

21. Schenkman M, Berger RA, Riley PO, Mann RW, Hodge WA. Whole-Body Movements During Rising to Standing from Sitting. Physical Therapy. 1990;70:638-648.

22. Santos AN, Pavão SL, Rocha NACF. Sit-to-stand movement in children with cerebral palsy: A critical review. Research in Developmental Disabilities. 2011;32:2243-2252.

23. McMillan AG, Scholz JP. Early development of coordination for the sit-tostand Task. Human Movement Science. 2000;19:21-57.

24. Carr J, Sheperd R. Reabilitação Neurológica Otimizando o desempenho motor. Barueri-SP: Editora Manole, 2008.

25. Hennington G, Johnson J, Penrose J, Barr K, McMulkin ML, Linden DWV. Effect of Bench Height on Sit-to-Stand in Children Without Disabilities and Children With Cerebral Palsy. Arch Phys Med Rehabil. 2004;85:70-76. 